\title{
PENGARUH E-LEARNING BERBASIS SCHOOLOGY TERHADAP AKTIVITAS BELAJAR PESERTA DIDIK KELAS X JURUSAN TEKNIK KOMPUTER DAN JARINGAN SMK SUMBER BUNGA
}

\author{
Dyan Yuliana $^{1)}$, Fengki Al Jufri ${ }^{2)}$ \\ STKIP PGRI Situbondo \\ email : pitikpitik23@gmail.com \\ email : fengkialjufri2005@gmail.com
}

\begin{abstract}
Abstrak
Seiring perkembangan teknologi informasi yang semakin pesat, kebutuhan akan suatu konsep dan mekanisme belajar mengajar berbasis Teknologi Informasi (TI) menjadi tak terelakkan lagi. Konsep yang kemudian terkenal dengan E-learning ini membawa pengaruh terjadinya proses transformasi pendidikan konvensional kedalam bentuk digital, baik secara isi maupun sistemnya. E-learning merupakan sebuah inovasi yang mempunyai kontribusi yang besar terhadap perubahan proses belajar, dimana proses belajar tidak lagi hanya mendengar uraian materi dari guru tetapi peserta didik juga melakukan aktivitas lain seperti mengamati, melakukan, dan lain-lain. E-learning Berbasis Schoology memberikan harapan baru sebagai alternatif solusi atas sebagian besar permasalahan pendidikan di indonesia, dengan fungsi yang dapat di sesuaikan dengan kebutuhan, baik sebagai suplemen (pelengkap), komplemen (pelengkap) ataupun substitusi (pengganti) atas kegiatan pembelajaran di dalam dan di luar jam pelajaran. Hal ini sesuai dengan hasil observasi pada kelas $\mathrm{X}$ bahwa saat ini pendidik masih menggunakan metode ceramah, yang mana peserta didik lebih aktif didalam kelas daripada diluar kelas. Dari permasalahan di atas, peneliti menyarankan untuk menggunakan media pembelajaran berbasis online yaitu schoology yaitu media pembelajaran berbasis online. Media pembelajaran online berbasis schoology tidak harus monoton di dalam kelas dan waktu yang dibutuhkan tidak selalu pada saat jam pelajaran berlangsung, dengan begitu peserta didik akan lebih aktif dan tidak bosan dalam belajar serta memiliki waktu yang lebih lama untuk belajar karena dapat dilakukan di luar jam pelajaran. Penelitian ini merupakan penelitian non eksperimental sehingga peneliti tidak melakukan percobaan atau eksperimen kepada subjek penelitian, akan tetapi peneliti hanya ingin mengetahui apakah ada pengaruh variabel $\mathrm{X}$ terhadap variabel $\mathrm{Y}$ sehingga pada penelitian ini menggunakan rancangan $e x$ post facto. Penentuan daerah penelitian dalam penelitian ini menggunakan metode
\end{abstract}


purposive sampling area yang ditetapkan di SMK Sumber Bunga karena daerah tersebut memenuhi syarat untuk dijadikan objek penelitian. Pada penelitian ini menggunakan metode penentuan responden penelitian secara populasi yaitu mengambil jumlah 50 responden peserta didik di SMK Sumber Bunga. Untuk memperoleh data dari sejumlah responden guna mengetahui ada tidaknya pengaruh pembelajaran di dalam jam pelajaran dan pembelajaran di luar jam pelajaran terhadap aktivitas belajar peserta didik menggunakan model angket. Data yang diperoleh dari angket yang bersifat kualitatif diubah menjadi kuantitatif. Hasil analisis data angket dapat dilihat pada lampiran. Dari hasil perhitungan analisis variansi garis regresi diperoleh Freg sebesar 6,4745. Dan apabila dikonsultasikan dengan $\mathrm{F}$ tabel untuk $\mathrm{db}=2 \mathrm{dan} \mathrm{db}=47$ dengan taraf signifikansi 5\% diperoleh 3,1951. Dengan demikian dari hasil perhitungan tersebut menunjukkan Freg lebih besar dari F-tabel yang berarti signifikansi secara mayor pembelajaran di dalam jam pelajaran dan pembelajaran di luar jam pelajaran terhadap aktivitas belajar. Selanjutnya dalam efektifitas garis regresi diperoleh sebesar 21,64\%. Ini berarti sumbangan efektif dari keseluruhan prediktor aktivitas belajar sebesar 21,64\% sedangkan variabel-variabel (faktor lain) yang tidak ikut diteliti sebesar $100 \%-21,64 \%=78,36 \%$. Sumbangan efektif (SE) prediktor $\left(\mathrm{X}_{1}\right)$ pembelajaran di dalam jam pelajaran terhadap kriterium (Y) aktivitas belajar peserta didik 13,55\%. Sumbangan efektif (SE) prediktor $\left(\mathrm{X}_{2}\right)$ pembelajaran di luar jam pelajaran terhadap kreterium (Y) aktivitas belajar peserta didik 8,09\%, ini menunjukkan bahwa pembelajaran di dalam jam pelajaran lebih berpengaruh terhadap aktivitas belajar sisiwa dibandingkan pembelajaran di luar jam pelajaran.

Kata Kunci : E-Learning Berbasis Schoology, Aktivitas Belajar Peserta Didik.

\section{Abstract}

As information technology develops rapidly, the need for information technology (IT) based concepts and teaching and learning mechanisms is inevitable. The concept which is then famous for E-learning brings the influence of the process of transforming conventional education into digital form, both in content and system. E-learning is an innovation that has a major contribution to changes in the learning process, where the learning process no longer only hears the material description from the teacher but students also carry out other activities such as observing, doing, and others. Schoology-based Elearning provides new hope as an alternative solution to most education problems in 
Indonesia, with functions that can be adjusted to the needs, both as a supplement (complement), complement (complementary) or substitution (substitute) for learning activities inside and outside of class hours. This is in accordance with the results of observations in class $\mathrm{X}$ that currently educators still use the lecture method, in which students are more active in the class than outside the class. From the above problems, the researcher suggests using online-based learning media, namely schoology, namely onlinebased learning media. Schoology-based online learning media do not have to be monotonous in class and the time needed is not always during the lesson, so students will be more active and not bored in learning and have a longer time to study because it can be done outside of school hours. This research is a non-experimental research so that researchers do not conduct experiments or experiments on research subjects, but researchers only want to know whether there is an influence of $\mathrm{X}$ variables on the $\mathrm{Y}$ variable so that in this study using the ex post facto design. The determination of the research area in this study used the purposive sampling area method that was determined at the Sumber Bunga Vocational School because the area fulfilled the requirements to become the object of research. In this study using the method of determining the research respondents in a population that is taking the number of 50 respondents of students at the Sumber Bunga Vocational School. To obtain data from a number of respondents in order to find out whether there is an influence of learning in lesson hours and learning outside of school hours on learning activities students use a questionnaire model. Data obtained from qualitative questionnaires are transformed into quantitative. The results of questionnaire data analysis can be seen in the attachment. From the results of the calculation of the regression line variance analysis Freg obtained 6.4745. And if consulted with $\mathrm{F}$ table for $\mathrm{db}$ $=2$ and $\mathrm{db}=47$ with a significance level of $5 \%$ obtained 3.1951. Thus from the results of these calculations show Freg is greater than F-table which means the major significance of learning in lesson hours and learning outside of school hours on learning activities. Furthermore, in the effectiveness of the regression line obtained by $21.64 \%$. This means that the effective contribution of the overall predictors of learning activities is $21.64 \%$ while the variables (other factors) that are not studied are $100 \%-21.64 \%=78.36 \%$. Effective contribution (SE) predictor $\left(\mathrm{X}_{1}\right)$ of learning in the lesson hours to the criteria $(\mathrm{Y})$ of student learning activities is $13.55 \%$. The effective contribution (SE) predictor $\left(\mathrm{X}_{2}\right)$ of learning outside the lesson to the creterium (Y) learning activities of students is $8.09 \%$, this 
indicates that learning in lesson hours has more influence on student learning activities than learning outside of school hours.

Keywords : Schoology-based E-learning, Learning Activities of Students.

\section{PENDAHULUAN}

Seiring dengan perkembangan teknologi informasi yang semakin pesat, kebutuhan akan suatu konsep dan mekanisme belajar mengajar berbasis TI menjadi tak terelakkan lagi. Konsep yang kemudian terkenal dengan E-learning ini membawa pengaruh terjadinya proses transformasi pendidikan konvensional ke dalam bentuk digital, baik secara isi dan sistemnya. Pembelajaran E-learning dapat mengakomodasi peserta didik memainkan peran yang lebih aktif dalam pembelajaran, peserta didik membuat perancangan dan mencari materi dengan usaha sendiri (Santyasa,2013:101).

Permasalahan yang dihadapi di SMK Sumber Bunga saat ini pendidik masih menggunakan metode ceramah, yang mana peserta didik lebih aktif didalam kelas daripada diluar kelas. Dari permasalahan di atas peneliti menyarankan untuk menggunakan media pembelajaran berbasis online yaitu schoology, dimana schoology adalah media pembelajaran berbasis online. Karna schoology tidak harus monoton di dalam kelas, dan waktu yang dibutuhkan tidak harus pada jam pelajaran, dengan begitu peserta didik akan lebih aktif dan tidak bosan dalam belajar.

E-learning Berbasis Schoology memberikan harapan baru sebagai alternatif solusi atas sebagian besar permasalahan pendidikan di indonesia, dengan fungsi yang dapat di sesuaikan dengan kebutuhan, baik sebagai suplemen (pelengkap), komplemen (pelengkap) ataupun substitusi (pengganti)atas kegiatan pembelajaran di dalam jam pelajaran. E-lerning merupakan sebuah inovasi yang mmpunyai kontribusi yang besar terhadap perubahan proses belajaran, dimana proses belajar tidak lagi hanya mendengar uraian materi dari guru tetapi peserta didik juga melakukan aktivitas lai seperti mengamati, melakukan dan lainlain (Ramadhani,2012:14).

Schoology memiliki berbagai kelebihan diantaranya, dapat dimuati dengan berbagai media pembelajaran seperti e-book, video, phet simulation, flash media player, link, swf, gambar, powerpoint dan masih banyak lagi. Selain itu pada program pembelajaran dengan E-learningschoology ini terdapat pula suatu forum untuk berdiskusi dan juga group.Peserta didik juga tidak dapat berbohong akan aktifitasnya dikarenakan segala aktifitas pada program ini akan terekam dan terpantau oleh guru dan terdapat pula absensi yang tidak dapat dimanipulasi. Segala aktifitas juga bergantung pada pengaturan yang telah disetting oleh guru sehingga peserta didik tidak dapat seenaknya saja melakukan aktifitas karena guru bisa saja mengeluarkannya dari kelas atau menonaktifkannya sementara waktu.Selain itu skor dari kuis juga dapat dilihat hasilnya secara langsung pada program ini sesuai kebijakan guru.

Namun E-learning ini masih memiliki kelemahan yaitu terkadang E-learning dengan schoology ini masih sering error jika jaringan internetnya lemah dan juga E-learning ini hanya bisa diakses secara online tidak bisa offline sehingga harus selalu terhubung dengan jaringan internet. 


\section{KAJIAN LITERATUR \\ 1.1 E-Learning}

E-learning tersusun dari dua bagian, yaitu 'e' yang merupakan singkatan dari 'electronica' dan 'learning' yang berarti 'pembelajaran'. Jadi E-learning berarti pembelajaran dengan menggunakan jasa bantuan perangkat elektronika.Di dalam pelaksanaannya, E-learning menggunakan jasa audio, video atau perangkat komputer atau kombinasi dari ketiganya. Dengan kata lain E-learning adalah pembelajaran yang dalam pelaksanaannya didukung oleh jasa teknologi seperti telepon, audio, videotape, transmisi satelite atau komputer.(Tafiardi, 2005:9) Sejalan dengan itu, Onno W. Purbo (dalam Amin, 2005:102) menjelaskan bahwa istilah "e" dalam E-learning adalah segala teknologi yang digunakan untuk mendukung usahausaha pengajaran lewat teknologi elektronik internet. Internet, satelit, tape audio/video, tv interaktif, dan CDROM adalah sebagian dari media elektronik yang digunakan. Pengajaran boleh disampaikan pada waktu yang sama(synchronously) ataupun pada waktu yang berbeda (asynchronously).

Secara lebih singkat william Horton mengemukakan bahwa (dalam Sembel, 2004:15) E-learning merupakan kegiatan pembelajaran berbasis web (yang bisa diakses dari internet). Tidak jauh berbeda dengan itu Brown, 2010:168-170 secara sederhana mengatakan bahwaE-learning merupakan kegiatan pembelajaran yang memanfaatkan jaringan (internet, LAN, WAN) sebagai metode penyampaian, interaksi, dan fasilitas yang didukung oleh berbagai bentuk layanan belajar lainnya. Selain itu, ada yang menjabarkan pengertian E-learning lebih luas lagi.Sebenarnya materi E-learning tidak harus di distribusikan secara on-line baik melalui jaringan lokal maupun internet.Interaksi dengan menggunakan internetpun bisa dijalankan secara on-line dan real-time ataupun recara off-line atau archieved. Distribusi secara offline menggunakan media CD/DVD pun termasuk pola E-learning. Dalam hal ini aplikasi dan materi belajar di kembangkan sesuai kebutuhan dan didistribusikan melalui media CD/DVD, selanjutnya pembelajar dapat memanfatkan CD/DVD tersebut dan belajar di tempat dimana dia berada (Lukmana,2006:16).

Karakteristik E-learning antara lain :

1) Memanfaatkan jasa teknologi elektronik. Sehingga dapat memperoleh informasi dan melakukan komunikasi dengan

2) Memanfaatkan media komputer, seperti jaingan komputer (computer networks) atau (digital media).

3) Menggunakan materi pembelajaran untuk dipelajari secara mandiri (self learning materials).

4) Materi pembelajaran dapat disimpan di komputer sehingga dapat diakses oleh guru dan peserta didik kapan saja dan di mana saja bila yang bersangkutan memerlukannya.

5) Memanfaatkan komputer untuk proses pembelajaran dan juga untuk mengetahui hasil kemajuan belajar, atau administrasi pendidikan serta untuk memperoleh informasi yang banyak dari berbagai sumber informasi.

E-learning mempermudah interaksi antara peserta didik dengan bahan/materi pelajaran.Peserta didik dapat saling berbagi informasi atau pendapat mengenai 
berbagai hal yang menyangkut pelajaran atau kebutuhan pengembangan diri peserta didik.Selain itu, guru dapat menempatkan bahan-bahan belajar dan tugas-tugas yang harus dikerjakan oleh peserta didik di tempat tertentu di dalam web untuk di akses oleh peserta didik.Sesuai dengan kebutuhan, guru dapat pula memberikan kesempatan kepada peserta didik untuk mengakses bahan belajar tertentu maupun soal-soal ujian yang hanya dapat diakses oleh peserta didik sekali saja dan dalam rentangan waktu tertentu pula (Website Kudos, 2002:23).

Secara lebih rinci, manfaat E-learning dapat dilihat dari 2 (dua) sudut, yaitu dari sudut peserta didik dan guru yaitu :

1. Peserta Didik

Dengan kegiatan E-learning dimungkinkan berkembangnya fleksibilitas belajar yang tinggi. Menurut Brown, 2010:107 ini dapat mengatasi peserta didikyang:

a. Belajar di sekolah-sekolah kecil di daerah-daerah miskin untuk mengikuti mata pelajaran tertentu yang tidak dapat.

b. Mengikuti program pendidikan keluarga di rumah (home schoolers) untuk mempelajari materi yang tidak dapat diajarkan oleh orang tuanya, seperti bahasa asing dan ketrampilan di bidang komputer,

c. Merasa phobia dengan sekolah atau peserta didik yang di rawat di rumah sakit maupun di rumah, yang putus sekolah tapi berminat melanjutkan pendidikannya, maupun peserta didik yang berada di berbagai daerah atau bahkan yang berada di luar negeri.

d. Tidak tertampung di sekolah konvensional untuk mendapatkan pendidikan.

2. Guru

Menurut (soekartawi2012:20) beberapa manfaat yang diperoleh guru adalah bahwa guru dapat :

a. Lebih mudah melakukan pemutakhiran bahan-bahan yang menjadi tanggung jawabnya sesuai dengan tuntutan perkembangan keilmuan yang terjadi.

b. Mengembangkan diri atau merakukan penelitian guna peningkatan wawasannya karena waktu luang yang dimiliki relatif lebih banyak.

c. Mengontrol kegiatan belajar peserta didik. Bahkan guru juga dapat mengetahui kapan peserta didiknya belajar, topik apa yang dipelajari, berapa lama sesuatu topik dipelajari, serta berapa kali topik tertentu dipelajari ulang.

d. Mengecek apakah peserta didik telah mengerjakan soalsoal latihan setelah mempelajari topik tertentu.

e. Memeriksa jawaban peserta didik dan memberitahukan hasilnya kepada peserta didik.

Selain itu, manfaat E-learning dengan penggunaan internet, khususnya dalam pembelajaran jarak jauh diantaranya :

a) Guru danpeserta didik dapat berkomunikasi dengan mudah dan cepat melalui fasilitas internet tanpa dibatasi oleh tempat, jarak dan waktu. Secara regular atau kapan saja kegiatan berkomunikasi bisa dilakukan.

b) Guru dan peserta didik dapat menggunakan materi pembelajaran yang ruang lingkup (scope) dan urutan (sekuensnya) sudah sistematis terjadwal melalui internet. 
c) Dengan E-learning dapat manjelaskan materi pembelajaran yang sulit dan rumit menjadi mudah dan sederhana. Selain itu, materi pembelajaran dapat disimpan dikomputer, sehiagga peserta didik dapat mempelajari kembali atau mengulang materi pembelajaran yang telah dipelajarinya setiap saat dan dimana saja sesuai dengan keperluannya.

d) Mempermudah dan mempercepat mengakses atau memperoleh banyak informasi yang berkaitan dengan materi pembelajaran yang dipelajarinya dari berbagai sumber informasi dengan melakukan akses di internet.

e) Internet dapat dijadikan media untuk melakukan diskusi antara guru dengan peserta didik, baik untuk seorang pembelajar, atau dalam jumlah pembelajar terbatas, bahkan massal.

f) Peran peserta didik rnenjadi lebih aktif mempelajari materi pembelajaran, memperoleh ilmu pengetahuan atau informasi secara mandiri, tidak mengandalkan pemberian dari guru, disesuaikan pula dengan keinginan dan minatnya terhadap materi pembelajaran.

g) Bagi pembelajar yang sudah bekerja dan sibuk dengan kegiatannya sehingga tidak mempunyai waktu untuk datang ke suatu lembaga pendidikan maka dapat mengakses internet kapanpun sesuai dengan waktu luangnya.

h) Relatif lebih efisien dari segi waktu, tempat dan biaya.

i) Dari segi biaya, penyediaan layanan internet lebih kecil biayanya dibanding harus membangun ruangan atau kelas pada lembaga pendidikan sekaligus memeliharanya, serta menggaji para pegawainya.

j) Memberikan pengalaman yang menarik dan bermakna bagi peserta didik karena dapat berinteraksi langsung, sehingga pemahaman

k) Kerja sama dalam komunitas online yang memudahkan dalam transfer informasi dan melakukan suatu komunikasi sehingga tidak akan kekurangan sumber atau materi pembelajaran.

1) Administrasi dan pengurusan terpusat sehingga memudahkan dalam melakukan akses atau dalam operasionalnya.

m) Membuat pusat perhatian dalam pembelajaran.

Setidaknya ada 3 (tiga) fungsi pembelajaran elektronik terhadap kegiatan pembelajaran di dalam jam pelajaran (classroom instruction), yaitu : (Lewis, 2002:67)

1. Suplemen (tambahan)

Dikatakan berfungsi sebagai suplemen, apabila peserta didik mempunyai kebebasan memilih, apakah akan memanfaatkan materi pembelajaran elektronik atau tidak. Dalam hal ini, tidak ada kewajiban/keharusan bagi peserta didik untuk mengakses materi pembelajaran elektronik. Sekalipun sifatnya opsional, peserta didik yang memanfaatkannya tentu akan memiliki tambahan pengetahuan atau wawasan.

2. Komplemen (pelengkap)

Dikatakan berfungsi sebagai komplemen, apabila materi elearning diprogramkan untuk melengkapi matei pembelajaran yang diterirna peserta didikdi dalam jam pelajaran (Lewis, 2002). Sebagai komplemen berarti materi.

E-learning diprogramkan untuk menjadi materi enrichment (pengayaan) atau remedial bagi peserta didik di dalam mengikuti kegiatan pembelajaran konvensional. 
sebagai enrichment, apabila peserta didik dapat dengan cepat menguasai/memahami materi pelajarun yang disampaikan guru secara tatap muka diberikan kesempatan untuk mengakses materi E-learning yang memang secara khusus dikembangkan untuk mereka.

Tujuannya agar semakin memantapkan tingkat penguasaan peserta didik terhadap materi plajaran yang disajikan guru di kelas.Sebagai remedial, apabila peserta didik mengalami kesulitan dalam memahami materi petajaran yang disampaikan guru secara tatap muka di kelas.Tujuannya agar peserta didik semakin lebih mudah memahami materi pelajaran yang disajikan guru di kelas.

3. Substitusi (pengganti)

Tujuan dari E-learning sebagai pengganti kelas konvensional adalah agar peserta didik dapat secara fleksibel mengelola kegiatan perkuliahan sesuai dengan waktu dan aktivitas lain sehari-hari. Ada 3 (tiga) alternatif model kegiatan pembelajaran yang dapat diikuti peserta didik antara lain :

a) Sepenuhnya secara tatap muka (konvensional).

b) Sebagian secara tatap muka dan sebagian lagi melalui internet.

c) Sepenuhnya melalui internet.

\subsection{Schoology}

Schoology menurut Aminoto dan Pathoni (2014:21) merupakan website yang memadukan E-learning dan jaringan sosial. Konsepnya sama seperti moodle, namun dalam hal E-learning dengan Schoology mempunyai banyak kelebihan. Menggunakan E-learning dengan Schoology juga lebih menguntungkan bila dibanding menggunakan moodle yaitu karena tidak memerlukan hosting dan pengelolaan Schoology lebih user friendly.Tentu fiturnya tidak selengkap moodle, namun untuk pembelajaran E-learning di sekolah sudah sangat memadai.

Fitur-fitur yang dimiliki Schoology sebagai berikut :

1) Courses, dengan menu courses kita dapat membuat kelas baru, bergabung dengan kelas yang sebelumnya sudah ada atau browsing melalui daftar kelas yang telah ditetapkan.

2) Groups, berfungsi seperti pesan dinding dimana anggota grup juga dapat memposting pesan dinding. Ketika bergabung dengan sebuah grup, kita dapat mencari bagian dari grup yang di inginkan.

3) Resources, untuk menjaga, melacak dokumen, file, dan gambar yang di upload dalam kelas.

4) Recent Activity, untuk menampilkan berita terbaru yang terdapat pada akun Schoology. Pengguna dapat mem-posting dan meng-update dalam akun serta memilih halaman mana yang akan di posting.

5) Calendar, untuk menampilkan halaman kalender yang telah diposting sebelumnya di Recent Activity.

6) Messages, untuk mengirimkan pesan atau melihat pesan antara sesama pengguna schoology.

7) People, untuk dapat melihat daftar pengguna dalam suatu kelas.

\subsection{Aktivitas Belajar Peserta Didik}


Menurut Mulyono (2001:26), Aktivitas artinya "kegiatan atau keaktifan". Jadi segala sesuatu yang dilakukan atau kegiatan-kegiatan yang terjadi baik fisik maupun non-fisik, merupakan suatu aktifitas.

Menurut Sriyono aktivitas adalah segala kegiatan yang dilaksanakan baik secara jasmani atau rohani.Sedangkan aktivitas peserta didik selama proses belajar mengajar merupakan salah satu indikator adanya keinginan peserta didik untuk belajar (Rosalia,2005:101). Aktivitas peserta didik merupakan kegiatan atau perilaku yang terjadi selama proses belajar mengajar. Kegiatan-kegiatan yang dimaksud adalah kegiatan yang mengarah pada proses belajar seperti bertanya, mengajukan pendapat, mengerjakan tugas- tugas, dapat menjawab pertanyaan guru dan bisa bekerjasama dengan peserta didik lain, serta tanggung jawab terhadap tugas yang diberikan.

Keaktifan peserta didik dalam proses pembelajaran akan menyebabkan interaksi yang tinggi antara guru dengan peserta didik ataupun dengan peserta didik itu sendiri. Hal ini akanmengakibatkan suasana kelas menjadi segar dan kondusif, dimana masing - masing peserta didik dapat melibatkan kemampuannya semaksimal mungkin. Aktivitas yang timbul dari peserta didikakan mengakibatkan pula terbentuknya pengetahuan dan keterampilan yang akan mengarah pada peningkatan prestasi. Aktivitas belajar merupakan suatu kegiatan yang dilakukan untuk menghasilkan perubahan pengetahuan-pengetahuan, nilai-nilai sikap, dan keterampilan pada peserta didik sebagai latihan yang dilaksanakan secara sengaja.

Dapat disimpulkan bahwa aktivitas belajar merupakan segala kegiatan yang dilakukan dalam proses interaksi (guru dan peserta didik) dalam rangka mencapai tujuan belajar. Aktivitas yang dimaksudkan di sini penekanannya adalah pada peserta didik, sebab dengan adanya aktivitas peserta didik dalam proses pembelajaran terciptalah situasi belajar aktif, seperti yang dikemukakan oleh Rochman Natawijaya(2005 : 31), belajar aktif adalah "Suatu sistem belajar mengajar yang menekankan keaktifan peserta didik secara fisik, mental intelektual dan emosional guna memperoleh hasil belajar berupa perpaduan antara aspek kognitif, afektif dan psikomotor".

Keaktifan peserta didik selama proses belajar mengajar merupakan salah satu indikator adanya keinginan atau motivasi peserta didik untuk belajar. Peserta didik dikatakan memiliki keaktifan apabila ditemukan ciri-ciri perilaku seperti: sering bertanya kepada guru atau peserta didik lain, mau mengerjakan tugas yang diberikan guru, mampu menjawab pertanyaan, senang diberi tugas belajar, dan lain sebagainya (Rosalia, 2005:45).

Berdasarkan pengetahuan tentang prinsip-prinsip diatas, diharapkan kepada guru untuk dapat mengembangkan aktivitas peserta didik. Menurut Zulfikri (2008: 56) jenis-jenis aktivitas yang dimaksud dapat digolongkan menjadi :

a. Visual Activities, yaitu segala kegiatan yang berhubungan dengan aktivitas peserta didik dalam melihat, mengamat, dan memperhatikan.

b. Oral Activities, yaitu aktivitas yang berhubungan dengan kemampuan peserta didik dalam mengucapkan, melafazkan, dan berfikir.

c. Listening Aktivities, aktivitas yang berhubungan dengan kemampuan peserta didik dalam berkonsentrasi menyimak pelajaran.

d. Motor Activities, yakni segala keterampilan jasmani peserta didik untuk mengekspresikan bakat yang dimilikinya. 
Menurut Jessica (2009:15-21), faktor-faktor yang mempengaruhi aktivitas belajar diantaranya :

1. Faktor Internal (dari dalam individu yang belajar)

Faktor yang mempengaruhi kegiatan belajar ini lebih ditekankan pada faktor dari dalam individu yang belajar. Adapun faktor yang mempengaruhi kegiatan tersebut adalah faktor psikologis, antara lain yaitu : motivasi, perhatian, pengamatan, tanggapan dan lain sebagainya.

2. Faktor Eksternal (dari luar individu yang belajar)

Pencapaian tujuan belajar perlu diciptakan adanya sistem lingkungan belajar yang kondusif. Hal ini akan berkaitan dengan faktor dari luar peserta didik. Adapun faktor yang mempengaruhi adalah mendapatkan pengetahuan, penanaman konsep dan keterampilan, dan pembentukan sikap.

\section{METODE PENELITIAN}

Dalam penelitian ini, rancangan penelitian yang digunakan adalah ex post facto menurut Karlinger dalam Sukardi, (2013:165). Penelitian ex post facto merupakan penelitian dimana variabel-variabel bebas telah terjadi ketika peneliti mulai dengan pengamatan variabel terikat dalam suatu penelitian.Pada penelitian ini keterkaitan antar variabel bebas dengan variabel bebas maupun antar variabel bebas dengan variabel terikat. Sudah terjadi secara alami dan peneliti dengan cara tersebut ingin melacak kembali jika dimungkinkan apa yang menjadi faktor penyebabnya. Kemudian (Sukardi, 2013:15) mengatakan bahwa suatu penelitian disebut ex post facto karena para peneliti berhubungan dengan variabel yang telah terjadi dan mereka tidak perlu memberikan perlakuan terhadap variabel yang di teliti.

Dengan demikian pada penelitian ini merupakan penelitian non eksperimental sehingga peneliti tidak melakukan percobaan atau eksperimen kepada subjek penelitian, akan tetapi peneliti hanya ingin mengetahui apakah ada pengaruh variabel $\mathrm{X}$ terhadap variabel $\mathrm{Y}$ sehingga pada penelitian ini menggunakan rancangan ex post facto.

Daerah penelitian berarti tempat dilaksanakannya penelitian dan perlu ditetapkan tidak bisa dilaksanakan disembarang tempat. Hal ini sesuai dengan pendapat Sutrisno Hadi (2011:67) yang mengemukakan bahwa, research sudah tentu tidak diselenggarakan dimana-mana atau disembarang tempat, melainkan diselenggarakan ditempat-tempat yang sudah ditentukan.

Selain itu didalam penelitian tidak ada atasan mutlak dalam menentukan berapa luas yang harus diteliti yang penting lokasi itu dapat mewakili dari keadaan populasi yang ada. Metode yang digunakan dalam penelitian ini adalah purposive sampling area menurut Sutrisno Hadi (2011:65) menyatakan bahwa metode purposive merupakan metode penentuan daerah penelitian yang sengaja dan berdasarkan ciriciri dan sifat populasi yang sudah diketahui sebelumnya.

Dari pendapat diatas bahwa penentuan tempat secara tegas dan jelas sangat diperlukan ada beberapa metode dalam penentuan daerah penelitian untuk itu penulis dalam penelitian ini menggunakan metode purposive sampling area.Sedangkan daerah penelitian yang ditetapkan itu di SMK Sumber Bunga. Penentuan daerah tersebut memenuhi syarat untuk dijadikan objek penelitian. 
Menurut (Sukardi, 2013:5) mengatakan bahwa responden adalah peserta didik yang dapat memberikan respon atau jawaban terhadap masalah yang diteliti.Dari pendapat diatas penulis dapat menyimpulkan bahwa responden adalah peserta didik yang dapat memberikan respon atau jawaban terhadap masalah yang diteliti, sedangkan responden yang dimaksud adalah peserta didik di SMK Sumber Bunga Tahun Pelajaran 2017/2018.

Dalam penentuan responden penelitian dapat dilakukan dengan dua cara yaitu dengan populasi atau sampel secara maksudnya individu, keadaan, serta benda dijadikan sumber data dimana data dianalisis untuk membuktikan hipotesis. Sedangkan penelitian sampel adalah sebagian atau bagian dari populasi yang diharapkan dapat mewakili populasi serta mencerminkan keadaan populasinya.

Pada penelitian ini menggunakan metode penentuan responden penelitian secara populasi yaitu mengambil jumlah 50 responden peserta didik kelas X Jurusan Teknik Komputer dan Jaringan SMK Sumber Bunga Tahun Pelajaran 2017/2018.

Sutrisno Hadi mengatakan bahwa "Baik buruknya suatu penelitian sangat bergantung kepada teknik-teknik pengumpulan datanya (2006:89).

Adapun metode pengumpulan data yang digunakan peneliti dalam penelitian ini adalah metode observasi, interview, angket dan dokumentasi.

\section{1) Metode Observasi}

Husaini Usman (2009:54) menyatakan bahwa "Obsevasi adalah pengamatan dan pencatatan yang sistematis terhadap gejala-gejala yang diteliti". Sutrisno Hadi (2011:53) mengatakan macam-macam metode observasi menjadi tiga, yaitu:

a. Observasi Partisipasi

Observasi partisipasi adalah metode observasi dimana orang mengadakan observasi turut ambil bagian dalam perikehidupan orang yang diobservasi.

b. Observasi Sistematis

Observasi sistematis mengguakan kerangka yang memuat faktor - faktor yang telah diatur lebih dahulu.

c. Observasi eksperimen

Observasi eksperimen adalah dilaksanakannya dalam situasi yang dikendalikan. Hal ini dilakukan untuk menghindari timbulnya faktor-faktor yang secara tidak sengaja mempengaruhi penyelidikan.

Dalam penelitian ini peneliti menggunakan metode observasi sistematis, sebab sebelum melakukan observasi terlebih dahulu telah dipersiapkan suatu kerangka yang sistematis. Hal ini untuk menjaga agar data-data yang diperoleh sesuai dengan tujuan yang akan ditempuh dan diinginkan. Dalam penelitian ini, observasi dilakukan secara langsung oleh peneliti terhadap guru Teknologi Informasi dan Komonikasi kelas X SMK SUMBER BUNGA.

\section{2) Metode Wawancara}

Metode interview atau wawancara digunakan dalam penelitian ini sebagai metode penunjang dalam pengumpulan data, keyakinan, perasaan, dan motif seseorang terhadap sesuatu sementara pihak responden tidak perlu dituntut untuk pandai membaca dan menulis, Hadari Nawawi berpendapat bahwa : "interview adalah sebagai usaha pengumpulan informasi dengan mengajukan sejumlah pertanyaan secara lisan untuk dijawab secara lisan pula“ (2008:111). 
Menurut Sanapiah Faisal pada prinsipnya wawancara sama dengan angket. Perbedaannya pada anngket pertanyaan diajukan secara tertulis, sedangkan pada wawancara, pertanyaan diajuan secara lisan (pengumpulan data bertatap muka dengan responden). Dalam wawancara tertentu saja pertanyaan - pertanyaan yang akan diajukan harus benar-benar dapat dimengerti oleh pengumpul data(interviewer)sebab dialah yang akan menyatakan dan menjelaskan kepada responden (2009:52).

Sementara itu Daryanto (2008 : 33 ) mengatakan bahwa wawacara atau interview adalah suatu cara yang digunakan untuk menempatkan jawaban dari responden dengan jalan tanya jawab sepihak. Dikatakan sepihak karena dalam wawancara ini responden tidak diberikan kesempatan sama sekali untuk mengajukan pertanyaan hanya diajukan oleh subyek evaluasi“".

Dari ketiga pendapat diatas menurut peneliti penggunaan metode interview dalam penelitian ini dirasa sangat tepat, karena memungkinkan diperoleh data yang lebih banyak, serta dapat dilengkapi data-data yang tidak ada atau belum bisa diperoleh dengan metode lain.

\section{3) Metode Angket}

Kuesioner adalah sejumlah pertanyaan tertulis yang digunakan untuk memperoleh informasi dari responden dalam arti laporan tentang pribadinya, atau hal-hal yang diketahui (Arikunto, 2011:128).Kuesioner yang digunakan dalam penelitian ini adalah kuesioner tertutup yaitu kuesioner yang sudah disediakan jawabannya sehingga responden hanya memilih jawab yang sesuai.

Penggunaan kuesioner atau angket diharapkan akan memudahkan bagi responden dalam memberikan jawaban karena alternatif jawaban telah tersedia, sehingga untuk menjawabnya hanya membutuhkan waktu yang cukup singkat. Pada setiap item soal disediakan tiga pilihan jawaban dengan skor masing-masing sebagai berikut :

a. Jika jawaban a, diberi skor 2 .

b. Jika jawaban b, diberi skor 1 .

Sehingga jika jawaban yang diberikan mendekati dengan jawaban yang diharapkan, maka semakin tinggi skor nilai yang diperoleh.

Metode angket ini digunakan untuk mengungkap data variabel aktivitas belajar peserta didik didalam dan diluar jam pelajaran setelah menerapkan $e$ learning berbasis schoology.

\section{4) Metode Dokumentasi}

Metode dokumenter adalah suatu pengumpulan data yang diperoleh dari catatan transkip atau dokumen-dokumen yang memang sudah ada. Hal ini sesuai dengan pendapat Suharsimi Arikonto bahwa "Metode dokumen mencari data mengenai variabel yang berupa catatan, transkip, buku, surat kabar, majalah prasasti, kegger dan agenda" (2008: 188 ).

Sedangkan Husaini Usman mengatakan bahwa: "Teknik pengumpulan data dengan dokumentasi ialah pengambilan data yang diperoleh melalui dokumendokumen" (2007: 73).

Berdasarkan kedua pendapat diatas penulis menyimpulkan bahwa metode dokumentasikan adalah suatu metode yang digunakan untuk memperoleh dan 
mendapatkan data dengan cara mempelajari dan mencari data yang sudah didokumentasikan.

Metode dokumentasi dimaksudkan untuk memperoleh data yang berasal dari surat-surat atau bukti-bukti serta catatan yang ada di tempat. Untuk memperoleh data tersebut dengan cara menghubungkan pihak yang akan dimintai keterangan mengenai dokumen yang diinginkan.

Untuk mengetahui seberapa besar pengaruh variabel $\mathrm{x}$ terhadap variabel $\mathrm{y}$, maka dilakukan teknik analisis data dengan menggunakan analisis regresi sebagai berikut :

\section{1) Persamaan Garis Regresi}

Untuk menemukan persamaan garis regresi, harga-harga koefisien prediktor dan bilangan konstantanya dapat dicari dari data yang diselidiki. Adapun rumus yang digunakan dalam mencari persamaan garis regresi yaitu :

$$
\mathrm{Y}=\mathrm{a}_{1} \mathrm{X}_{1}+\mathrm{a}_{2} \mathrm{X}_{2}+\mathrm{K}
$$

\section{2) Mencari Koefisien Korelasi Berganda}

Guna mencari/menghitung tingkat signifikan hubungan antara kreterium (Y) dengan $X_{1}$ dan $X_{2}$ menggunakan skor deviasi dengan rumus berikut ini :

$$
\operatorname{Ry}_{(1,2,)}=\sqrt{\frac{a_{1} \sum x_{1} y+a^{2} \sum x_{2} y}{\sum y^{2}}}
$$

Keterangan :

$\operatorname{Ry}_{(1,2)}=$ Koefisien korelasi antara $\mathrm{Y}$ dengan $\mathrm{X}_{1}$ dan $\mathrm{X}_{2}$

$\mathrm{a}_{1} \quad=$ Koefisien prediktor kedisplinan belajar $\mathrm{X}_{1}$

$\mathrm{a}_{2} \quad=$ Koefisienprediktor minat belajar $\mathrm{X}_{2}$

$\mathrm{X}_{1} \mathrm{Y}=$ Jumlah Produk antara $\mathrm{X}_{1}$ dengan $\mathrm{Y}$

$\mathrm{X}_{2} \mathrm{Y}=$ Jumlah Produk antara $\mathrm{X}_{2}$ dengan $\mathrm{Y}$

$y^{2} \quad=$ Jumlah kuadrat Kreterium Y

\section{3) Analisis Variansi Garis Regresi}

Analisa variansi garis regresi ini digunakan untuk menguji signifikasi pengaruh predikator (variabel bebas) terhadap (hasil belajar) secara serempak dengan menggunakan rumus :

$$
\mathrm{F}_{\mathrm{reg}}=\frac{R^{2}(N-m-1)}{m\left(1-R_{2}\right)}
$$

\section{Dimana :}

$\mathrm{R}^{2}=\mathrm{Ry}_{(1,2)}$ dikuadratkan

$\mathrm{M}=$ Jumlah Prediktor

$\mathrm{N}=$ Jumlah Responden

$$
\mathrm{JK}_{\mathrm{reg}}=\mathrm{a}_{1} \Sigma \mathrm{x}_{1} \mathrm{y}+\mathrm{a}_{2} \Sigma \mathrm{x}_{2} \mathrm{y} ; \mathrm{Jk}_{\mathrm{tot}}=\Sigma \mathrm{y}^{2}
$$




$$
\mathrm{EGR}=\frac{J K_{r e g}}{J K_{t_{o t}}} x 100 \%
$$

\section{4) Efektifitas Garis Regresi (EGR)}

Efektifitas Garis Regresi (EGR) atau sumber efektif keseluruhan prediktor (variabel bebas) yang diteliti terhadap kreterium (variabel terikat) adalah dengan cara membandingkan $\mathrm{JK}_{\text {reg }}$ dengan $\mathrm{Jk}_{\text {total }}$. EGR ini digunakan untuk mengetahui seberapa besar pengaruh $\mathrm{X} 1$ dan $\mathrm{X} 2$ terhadap $\mathrm{Y}$, yaitu dengan rumus :

$$
\begin{gathered}
\mathrm{JK}_{\mathrm{reg}}=\mathrm{a}_{1} \Sigma \mathrm{x}_{1} \mathrm{y}+\mathrm{a}_{2} \Sigma \mathrm{x}_{2} \mathrm{y} ; \mathrm{Jk}_{\mathrm{tot}}=\Sigma \mathrm{y}^{2} \\
\mathrm{EGR}=\frac{J K_{\text {reg }}}{J K_{\text {tot }}} \times 100 \%
\end{gathered}
$$

\section{5) Sumbangan Efektif (SE)}

Sedangkan untuk menghitung sumbangan efektif (SE) atau besar pengaruh masing-masing (variabel bebas) terhadap (variabel terikat) dengan rumus :

$$
\begin{aligned}
& \mathrm{SE} \% \mathrm{X}_{1}=\frac{a_{1} \sum x_{1} y}{J K_{r e g}} \times 100 \% \\
& \mathrm{SE} \% \mathrm{X}_{2}=\frac{a_{2} \sum x_{2} y}{J K_{r e g}} \times 100 \%
\end{aligned}
$$

3.5.2 Tabel 1. Interpretasi Koefisien Kolerasi

\begin{tabular}{|c|c|}
\hline Besar Nilai R & Interpretasi \\
\hline Antara $\pm 0,00 \mathrm{~s} / \mathrm{d} \pm 0,20$ & Tidak ada/hampir tak ada pengaruh \\
Antara $\pm 0,21 \mathrm{~s} / \mathrm{d} \pm 0,40$ & Pengaruh rendah \\
Antara $\pm 0,41 \mathrm{~s} / \mathrm{d} \pm 0,60$ & Pengaruh sedang \\
Antara $\pm 0,61 \mathrm{~s} / \mathrm{d} \pm 0,80$ & Pengaruh tinggi \\
Antara $\pm 0,81 \mathrm{~s} / \mathrm{d} \pm 1,00$ & Pengaruh sempurna \\
\hline
\end{tabular}

(Sumber : Sugiono 2014 hal : 109)

\section{HASIL DAN PEMBAHASAN}

\subsection{Data Aktivitas Angket dan Aktivitas Belajar Peserta Didik}

Tabel 2. Data Pembelajaran Di Dalam Jam Pelajaran, Pembelajaran Di Luar Jam Pelajaran, dan Aktivitas Belajar

\begin{tabular}{|c|c|c|c|}
\hline No. & $\mathrm{X}_{1}$ & $\mathrm{X}_{2}$ & $\mathbf{Y}$ \\
\hline 1 & 16 & 18 & 80 \\
\hline
\end{tabular}




\begin{tabular}{|c|c|c|c|}
\hline 2 & 18 & 15 & 75 \\
\hline 3 & 20 & 18 & 95 \\
\hline 4 & 19 & 19 & 80 \\
\hline 5 & 20 & 20 & 95 \\
\hline 6 & 18 & 19 & 95 \\
\hline 7 & 18 & 14 & 85 \\
\hline 8 & 20 & 14 & 80 \\
\hline 9 & 20 & 19 & 90 \\
\hline 10 & 20 & 14 & 95 \\
\hline 11 & 19 & 19 & 95 \\
\hline 12 & 20 & 14 & 90 \\
\hline 13 & 20 & 20 & 80 \\
\hline 14 & 19 & 14 & 80 \\
\hline 15 & 20 & 14 & 80 \\
\hline 16 & 20 & 18 & 80 \\
\hline 17 & 18 & 15 & 80 \\
\hline 18 & 20 & 15 & 95 \\
\hline 19 & 20 & 20 & 85 \\
\hline 20 & 18 & 19 & 95 \\
\hline 21 & 20 & 15 & 90 \\
\hline 22 & 18 & 14 & 80 \\
\hline 23 & 19 & 15 & 85 \\
\hline 24 & 19 & 14 & 80 \\
\hline 25 & 19 & 15 & 90 \\
\hline 26 & 20 & 20 & 85 \\
\hline 27 & 20 & 16 & 85 \\
\hline 28 & 19 & 20 & 90 \\
\hline 29 & 19 & 19 & 80 \\
\hline 30 & 15 & 19 & 80 \\
\hline 31 & 15 & 19 & 80 \\
\hline 32 & 20 & 18 & 85 \\
\hline 33 & 20 & 20 & 85 \\
\hline 34 & 20 & 14 & 85 \\
\hline 35 & 20 & 15 & 80 \\
\hline 36 & 20 & 20 & 80 \\
\hline 37 & 20 & 18 & 85 \\
\hline 38 & 20 & 15 & 75 \\
\hline 39 & 20 & 20 & 90 \\
\hline 40 & 16 & 16 & 75 \\
\hline 41 & 16 & 15 & 80 \\
\hline
\end{tabular}




\begin{tabular}{|c|c|c|c|}
\hline 42 & 20 & 20 & 90 \\
\hline 43 & 20 & 19 & 85 \\
\hline 44 & 19 & 16 & 80 \\
\hline 45 & 20 & 20 & 95 \\
\hline 46 & 20 & 20 & 90 \\
\hline 47 & 20 & 20 & 90 \\
\hline 48 & 18 & 13 & 75 \\
\hline 49 & 20 & 13 & 85 \\
\hline 50 & 20 & 12 & 80 \\
\hline Jumlah & $\mathbf{9 5 5}$ & $\mathbf{8 4 8}$ & $\mathbf{4 2 4 5}$ \\
\hline
\end{tabular}

\subsection{Analisis Data}

\subsubsection{Persamaan Garis Regresi}

Untuk mengetahui ada tidaknya pengaruh e-learning berbasis schoology yang digunakan dalam penelitian, diperoleh data dari penyebaran angket sebagai berikut :

$\sum \mathrm{X}_{1}=955 \sum \mathrm{X}_{2}=848 \quad \sum \mathrm{Y}_{=}=4245$

$$
\sum \mathrm{X}_{1}^{2}=18349 \sum \mathrm{X}_{2}^{2}=14788
$$$$
\sum Y^{2}=362275
$$

$$
\sum \mathrm{X}_{1} \mathrm{Y}=81250 \sum \mathrm{X}_{2} \mathrm{Y}=72255 \quad \sum \mathrm{X}_{1} \mathrm{X}_{2}=16212
$$

Mencari skor deviasi (skor halus) :

$$
\begin{aligned}
\sum \mathrm{X}_{1}{ }^{2} & =\sum \mathrm{X}_{1}{ }^{2}-\frac{\left(\sum \mathrm{x}_{1}\right)^{2}}{\mathbf{N}} \\
& =18349-\frac{(955)^{2}}{50} \\
& =18349-18240,5 \\
& =108,5 \\
\sum \mathrm{X}_{2}{ }^{2} & =\sum \mathrm{X}_{2}{ }^{2}-\frac{\left(\sum \mathrm{x}_{2}\right)^{2}}{\mathbf{N}} \\
& =14788-\frac{(848)^{2}}{50} \\
& =14788-14382,08 \\
& =405,92 \\
\sum \mathrm{Y}^{2} & =\sum \mathrm{Y}^{2}-\frac{\left(\sum \mathrm{Y}\right)^{2}}{\mathrm{~N}} \\
& =362275-\frac{(4245)^{2}}{50} \\
& =362275-360400,5 \\
& =1874,5 \\
\sum \mathrm{X}_{1} \mathrm{Y} & =\sum \mathrm{X}_{1} \mathrm{Y}-\frac{\left(\sum \mathrm{x}_{1}\right)(\Sigma \mathrm{Y})}{\mathrm{N}}
\end{aligned}
$$




$$
\begin{aligned}
& =81250-\frac{(955)(4245)}{50} \\
& =81250-81079,5 \\
& =170,5 \\
\Sigma X_{2} Y & =\sum X_{2} Y-\frac{\left(\sum \mathrm{X}_{2}\right)\left(\sum \mathrm{Y}\right)}{\mathrm{N}} \\
& =72255-\frac{(848)(4245)}{50} \\
& =72255-71995,2 \\
& =259,8 \\
\Sigma \mathrm{X}_{1} \mathrm{X}_{2} & =\sum \mathrm{X}_{1} \mathrm{X}_{2}-\frac{\left(\sum \mathrm{x}_{1}\right)\left(\sum \mathrm{x}_{2}\right)}{\mathrm{N}} \\
& =16212-\frac{(955)(848)}{50} \\
& =16212-16196,8 \\
& =15,2
\end{aligned}
$$

Mencari persamaan garis regresi berganda bisa dilakukan dengan menggunakan metode skor deviasi, untuk mencari persamaan garis regresinya sebagai berikut :

$$
\mathbf{Y}=\mathbf{a}_{1} \mathbf{x}_{1}+\mathbf{a}_{2} \mathbf{x}_{2}+\mathbf{K}
$$

Data halus (Skor Deviasi) diaplikasikan pada persamaan simultan untuk menentukan $\mathrm{a}_{1}$ dan $\mathrm{a}_{2}$ yaitu :

$$
\begin{aligned}
& \sum \mathrm{X}_{1} \mathbf{Y}=\mathrm{a}_{1} \sum \mathrm{X}_{1}{ }^{2}+\mathrm{a}_{2} \sum \mathrm{X}_{1} \mathrm{X}_{2} \\
& \sum \mathrm{X}_{2} \mathrm{Y}=\mathrm{a}_{1} \sum \mathrm{X}_{1} \mathrm{X}_{2}+\mathrm{a}_{2} \sum \mathrm{X}_{2}^{2} \\
& \begin{array}{ll|ll}
170,5 & =108,5 \mathrm{a}_{1} \quad+15,2 \mathrm{a}_{2} & : 102,8333 \quad \text { persamaan (1) }
\end{array} \\
& 259,8=15,2 \mathrm{a}_{1}+405,92 \mathrm{a}_{2} \quad: 356,2381 \quad \text { persamaan }(2) \\
& 11,2171=7,1381 \mathrm{a}_{1}+\mathrm{a}_{2} \\
& \begin{array}{c}
0,6400=0,0374 \mathrm{a}_{1}+\mathrm{a}_{2} \\
\hline 10,5771=7,1007 \mathrm{a}_{1}
\end{array} \\
& \mathrm{a}_{1} \quad=\frac{10,5771}{7,1007} \\
& \mathrm{a}_{1}=1,489 \\
& 170,5=108,5 \mathrm{a}_{1}+15,2 \mathrm{a}_{2} \\
& 170,5=108,5(1,4896)+15,2 \mathrm{a}_{2} \\
& 170,5=176,8216 \\
& \mathrm{a}_{2} \quad=\frac{170,5}{176,8216} \\
& a_{2}=0,584
\end{aligned}
$$

Untuk mencari persamaan garis regresi telah diketahui sebelumnya bahwa 


$$
\begin{aligned}
& \overline{\mathrm{X}}_{1}=\frac{\sum \mathrm{X}_{1}}{\mathrm{~N}}=\frac{955}{50}=19,1 \\
& \overline{\mathrm{X}}_{2}=\frac{\sum \mathrm{X}_{2}}{\mathrm{~N}}=\frac{848}{50}=16,96 \\
& \overline{\mathrm{Y}}=\frac{\sum \mathrm{Y}}{\mathrm{N}}=\frac{4245}{50}=84,9 \\
& \mathrm{a}_{1}=\mathbf{1 , 4 8 9} \\
& \mathrm{a}_{2}=\mathbf{0 , 5 8 4}
\end{aligned}
$$

Dari nilai koefisien di atas dapat dicari besar nilai konstantanya dan sekaligus persamaan garis regresinya.

$$
\begin{aligned}
& \mathrm{Y}=\mathrm{a}_{1}\left(\mathrm{X}_{1}-\overline{\mathrm{X}}_{1}\right)+\mathrm{a}_{2}\left(\mathrm{X}_{2}-\overline{\mathrm{X}}_{2}\right)+\overline{\mathrm{Y}} \\
& \mathrm{Y}=1,4896\left(\mathrm{X}_{1}-19,1\right)+0,584\left(\mathrm{X}_{2}-16,96\right)+84,9 \\
& \mathrm{Y}=1,4896 \mathrm{X}_{1}-28,4514+0,584 \mathrm{X}_{2}-9,9046+84,9 \\
& \mathrm{Y}=1,4896 \mathrm{X}_{1}+0,584 \mathrm{X}_{2}+46,544
\end{aligned}
$$

Dari perhitungan di atas dapat dituliskan persamaan garis regresinya untuk variabel bebas terhadap variabel terikatnya ialah :

$$
Y=1,4896 X_{1}+0,584 X_{2}+46,544
$$

\section{a) Konstanta}

Konstanta sebesar 46,544 mempunyai arti adanya pengaruh yang positif terhadap aktivitas belajar peserta didik kelas X Jurusan Teknik Komputer dan Jaringan SMK Sumber Bunga yaitu e-learning berbasis schoology tetap atau konstan akan mempengaruhi aktivitas belajar peserta didik sebesar 46,544 dengan variabel pengganggu yang tidak diteliti.

b) Koefisien Regresi Pembelajaran Di Dalam Jam Pelajaran $\left(\mathrm{x}_{1}\right)$

Koefisien regresi pembelajaran di dalam jam pelajaran $\left(\mathrm{X}_{1}\right)$ menunjukkan besarnya perubahan $\mathrm{X}_{1}$ terhadap $\mathrm{Y}$. Perubahan tersebut bersifat positif atau searah, artinya apabila salah satu variabel mengalami kenaikan, akan mengakibatkan kenaikan pada variabel yang lain. Apabila terjadi perubahan variabel pembelajaran di dalam jam pelajaran $\left(\mathrm{X}_{1}\right)$ sebesar $1 \%$ dengan anggapan variabel pembelajaran di luar jam pelajaran $\left(\mathrm{X}_{2}\right)$ sama dengan nol (konstan), menyebabkan perubahan variabel aktivitas belajar peserta $\operatorname{didik}(\mathrm{Y}) \operatorname{sebesar} 1,4896$.

\section{c) Koefisien Regresi Pembelajaran Di Luar Jam Pelajaran $\left(\mathrm{X}_{2}\right)$}

Koefisien regresipembelajaran di luar jam pelajaran $\left(\mathrm{X}_{2}\right)$ menunjukkan besarnya perubahan $\mathrm{X}_{2}$ terhadap $\mathrm{Y}$. Perubahan tersebut bersifat positif atau searah, artinya apabila salah satu variabel mengalami kenaikan, akan menyebabkan kenaikan pada variabel yang lain. Apabila terjadi perubahan variabel pembelajaran di luar jam 
pelajaran $\left(\mathrm{X}_{2}\right)$ sebesar $1 \%$ dengan anggapan variabel pembelajaran di dalam jam pelajaran $\left(\mathrm{X}_{1}\right)$ sama dengan nol (konstan), menyebabkan perubahan variabel aktivitas belajar peserta didiksebesar 0,584 .

\subsubsection{Menghitung Koefisien Korelasi Antara Variabel Terikat (Y) Dengan Variabel Bebas $\left(X_{1} \operatorname{dan} X_{2}\right)$}

Untuk mengetahui sejauh mana pengaruh antara pembelajaran di dalam jam pelajaran dan pembelajaran di luar jam pelajaran terhadap aktivitas belajar peserta didik kelas X Jurusan Teknik Komputer dan Jaringan SMK Sumber Bunga, maka dilakukan analisis data dan pengujian hipotesis mayor dengan menghitung korelasi antara $\mathrm{X}_{1}$ dan $\mathrm{X}_{2}$ secara serentak dengan variabel Y.

$$
\begin{aligned}
& \mathrm{R}_{\mathrm{y}(1,2)}=\sqrt{\frac{a_{1} \sum x_{1} y+a_{2} \sum x_{2} y}{\sum y^{2}}} \\
& =\sqrt{\frac{(1,4896)(170,5)+(0,9642)(259,8)}{1874,5}} \\
& =\sqrt{\frac{253,9768+250,4992}{1874,5}} \\
& =\sqrt{\frac{504,476}{1874,5}} \\
& =\sqrt{0,2691} \\
& \mathrm{R}_{\mathrm{y}(1,2)}=0,5188 \\
& \mathrm{R}_{\mathrm{y}(1,2)^{2}}=0,269
\end{aligned}
$$

\subsubsection{Menghitung Analisis Farian Regresi (F reg)}

Hasil dari koefisien korelasi di atas perlu diadakan uji signifikansi untuk mengetahui signifikan atau tidaknya nilai yang diperoleh dua variabel bebas secara serentak terhadap variabel terikat dengan rumus sebagai berikut :

$$
\begin{aligned}
\text { F reg } & =\frac{R^{2}(\mathrm{~N}-\mathrm{m}-1)}{\mathrm{m}\left(1-R^{2}\right)} \\
& =\frac{0,269(50-2-1)}{2(1-0,269)} \\
& =\frac{0,169(47)}{2(0,831)} \\
& =\frac{0,269(47)}{2(1-0,269)}
\end{aligned}
$$




$$
\begin{aligned}
& =\frac{12,643}{1,462} \\
\text { F reg } & =\mathbf{8 , 6 4 8}
\end{aligned}
$$

Dengan $\mathrm{db}=\mathrm{m}$ lawan $\mathrm{n}-\mathrm{m}-1$ atau 2 lawan 47 dengan $=0,05, \mathrm{~F}$ tabel 3,1951, perhitungan diatas $\mathrm{F}$ reg sebesar 8,648 maka $\mathrm{F}$ reg $>\mathrm{F}$ tabel. Hipotesis nihil $\left(\mathrm{H}_{0}\right)$ ditolak dan hipotesis kerja $\left(\mathrm{H}_{\mathrm{a}}\right)$ diterima, oleh sebab itu dapat dikatakan signifikan atau ada pengaruh. Hipotesis yang diterima yaitu ada pengaruh yang signifikan antara pembelajaran menggunakan $e$ learning berbasis schoology di dalam jam pelajaran dan di luar jam pelajaran terhadap aktivitas belajar peserta didik kelas X Jurusan Teknik Komputer dan Jaringan SMK Sumber Bunga.

Tabel 3. Perbandingan F-hitung dengan F-tabel

\begin{tabular}{|c|c|c|c|c|}
\hline Hipotesis & $\begin{array}{c}\text { F- } \\
\text { Hitung }\end{array}$ & F-Tabel\% & $\begin{array}{c}\text { Keputusan } \\
\text { Statistik }\end{array}$ & $\begin{array}{c}\text { Keputusan } \\
\text { Akhir }\end{array}$ \\
\hline $\mathrm{Ha}$ & $\mathbf{8 , 6 4 8}$ & 3,1951 & Signifikan & Diterima \\
\hline
\end{tabular}

\subsubsection{Menghitung Uji t}

Hasil dari koefisien korelasi di atas perlu diadakan uji signifikansi untuk mengetahui signifikan atau tidaknya nilai yang diperoleh tiap variabel bebas terhadap variabel terikat dengan menggunakan uji-t, rumusnya sebagai berikut :

1) Uji $-\mathrm{t}$ minor $X_{1}$ (pembelajaran di dalam jam pelajaran) terhadap $Y$ (aktivitas belajar).

$$
\begin{aligned}
\mathrm{t}_{\text {hitung }} & =\frac{\mathrm{R}_{1} \sqrt{\mathrm{N}-2}}{\sqrt{1-\mathrm{R}^{2}}} \\
\mathrm{t}_{\text {hitung }} & =\frac{0,375 \sqrt{50-2}}{\sqrt{1-0,141^{2}}} \\
\mathrm{t}_{\text {hitung }} & =\frac{0,375 \sqrt{48}}{\sqrt{1-0,141}} \\
\mathrm{t}_{\text {hitung }} & =\frac{2,598}{\sqrt{0,859}} \\
\mathrm{t}_{\text {hitung }} & =\frac{2,598}{0,927} \\
\mathrm{t}_{\text {hitung }} & =2,802
\end{aligned}
$$

a. Menentukan hipotesis

Ho : Secara parsial tidak ada pengaruh signifikan antara pembelajaran di dalam jam pelajaran terhadap aktivitas belajar. 
Ha : Secara parsial ada pengaruh signifikasi antara pembelajaran di dalam jam pelajaran terhadap aktivitas belajar.

b. Menentukan tingkat signifikansi

Tingkat signifikansi menggunakan $a=5 \%$.

c. Menentukan $\mathrm{t}$ - hitung

Berdasarkan data hasil parsial pembelajaran di dalam jam pelajaran diperoleh $\mathrm{t}$ - hitung sebesar 2,802.

d. Menentukan $\mathrm{t}$ - hitung

Tabel distribusi t dicari pada $a=5 \%: 2=2,5 \%$ (uji 2 sisi) dengan derajat kebebasan (df) n-k-1 atau 50-2-1 = 47 (n adalah jumlah kasus dan k adalah jumlah variabel independen). Dengan pengujian 2 sisi (signifikansi=0,025) aktivitas pembelajaran di dalam jam pelajarandiperoleh t tabel sebesar 2,012.

e. Kriteria pengujian

Ha diterima jika t-tabel $<\mathrm{t}$ - hitung atau t-hitung $>\mathrm{t}$-tabel.

Ho ditolak jika t-hitung $<\mathrm{t}$-tabel atau t-hitung $<\mathrm{t}$-tabel.

f. Membandingkan t-hitung dengan -tabel

Nilai t-hitung > t- tabel $(2,802>2,012)$, maka Ha diterima .

g. Kesimpulan

Oleh karena itu t-hitung > t-tabel $(2,802>2,012)$ maka Ha diterima, artinya secara parsial ada pengaruh pembelajaran di dalam jam pelajaran terhadap aktivitas belajar. Jadi dari kasus ini dapat disimpulkan bahwa secara parsial pembelajaran di dalam jam pelajaran berpengaruh terhadap aktivitas belajar.

2) Uji - t minor $X_{2}$ (pembelajaran di luar jam pelajaran) terhadap $Y$ (aktivitas belajar).

$$
\begin{aligned}
\mathrm{t}_{\text {hitung }} & =\frac{\mathrm{R}_{2} \sqrt{\mathrm{N}-2}}{\sqrt{1-\mathrm{R}^{2}}} \\
\mathrm{t}_{\text {hitung }} & =\frac{0,294 \sqrt{50-2}}{\sqrt{1-0,086^{2}}} \\
\mathrm{t}_{\text {hitung }} & =\frac{0,294 \sqrt{48}}{\sqrt{1-0,086}} \\
\mathrm{t}_{\text {hitung }} & =\frac{2,037}{\sqrt{0,914}} \\
\mathrm{t}_{\text {hitung }} & =\frac{2,037}{0,956} \\
\mathrm{t}_{\text {hitung }} & =2,131
\end{aligned}
$$

a. Menentukan hipotesis

Ho : Secara parsial tidak ada pengaruh signifikan antara pembelajaran di luar jam pelajaran terhadap aktivitas belajar. 
Ha : Secara parsial ada pengaruh signifikasi antara pembelajaran di luar jam pelajaran terhadap aktivitas belajar.

b. Menentukan tingkat signifikansi

Tingkat signifikansi menggunakan $a=5 \%$.

c. Menentukan $\mathrm{t}$ - hitung

Berdasarkan data hasil parsial pembelajaran di luar jam pelajaran diperoleh $\mathrm{t}$ - hitung sebesar 2,131.

d. Menentukan $\mathrm{t}$ - hitung

Tabel distribusi t dicari pada $a=5 \%: 2=2,5 \%$ (uji 2 sisi) dengan derajat kebebasan (df) n-k-1 atau 50-2-1 = 47 (n adalah jumlah kasus dan $\mathrm{k}$ adalah jumlah variabel independen). Dengan pengujian 2 sisi (signifikansi=0,025) aktivitas belajar diperoleh $\mathrm{t}$ tabel sebesar 2,012.

e. Kriteria pengujian

Ha diterima jika t-tabel $<\mathrm{t}$ - hitung atau t-hitung $>\mathrm{t}$-tabel.

Ho ditolak jika t-hitung $<\mathrm{t}$-tabel atau t-hitung $<\mathrm{t}$-tabel.

f. Membandingkan t-hitung dengan -tabel

Nilai t-hitung $>$ t- tabel $(2,311>2,012)$ maka Ha diterima.

g. Kesimpulan

Oleh karena itu t-hitung >t-tabel $(2,131>2,012)$ maka Ha diterima, artinya secara parsial ada pengaruh signifikan pembelajaran di luar jam pelajaran terhadap aktivitas belajar. Jadi dari kasus ini dapat disimpulkan bahwa secara parsial pembelajaran di luar jam pelajaran berpengaruh terhadap aktivitas belajar.

\subsubsection{Menghitung Efektifitas Garis Regresi (EGR)}

Sumbangan efektif untuk mengetahui sumbangan masing-masing variabel bebas terhadap variabel terikat yaitu sebagai berikut :

$$
\begin{aligned}
\text { IK total } & =\sum \mathrm{Y}^{2}-\frac{\left(\sum \mathrm{Y}\right)^{2}}{\mathrm{~N}} \\
& =362275-\frac{(4245)^{2}}{50} \\
& =1.874,5 \\
\text { IK reg } & =\mathrm{a}_{1} \sum \mathrm{x}_{1} \mathrm{y}+\mathrm{a}_{2} \sum \mathrm{x}_{2} \mathrm{y} \\
& =(1,4896)(170,5)+(0,584)(259,8) \\
& =253,9768+151,7232 \\
& =405,7 \\
\text { EGR }= & \frac{J K_{\text {Re } g}}{J K_{\text {total }}} \times 100 \%
\end{aligned}
$$




$$
\begin{aligned}
& =\frac{405,7}{1874,5} \times 100 \% \\
& =21,64 \%
\end{aligned}
$$

Setelah data dimasukkan dan diolah maka dapat diketahui besarnya EGR adalah 21,64\%.

\subsubsection{Menghitung Sumbangan Relatif (SR) Variabel Bebas Secara Serentak Terhadap Variabel Terikat}

Sumbangan relatif digunakan untuk mengetahui besar pengaruh variabel bebas secara serentak terhadap variabel terikat yang dilakukan dengan cara :

a) Sumbangan Relatif $\mathrm{X}_{1}$ terhadap $\mathrm{Y}$

$$
\begin{aligned}
\text { SR } \% \mathrm{X}_{1} & =\frac{\mathrm{a}_{1} \sum \mathrm{x}_{1} \mathrm{y}}{\mathrm{JK} \mathrm{reg}} \times 100 \% \\
& =\frac{253,9768}{405,7} \times 100 \% \\
& =62,60 \%
\end{aligned}
$$

b) Sumbangan Relatif $\mathrm{X}_{2}$ terhadap $\mathrm{Y}$

$$
\begin{aligned}
\text { SR } \% \mathrm{X}_{2} & =\frac{\mathrm{a}_{2} \sum \mathrm{x}_{2} \mathrm{y}}{\mathrm{JK} \text { reg }} \times 100 \% \\
& =\frac{151_{2} 7232}{405,7} \times 100 \% \\
& =37,40 \%
\end{aligned}
$$

\subsubsection{Menghitung Sumbangan Efektif (SE) Tiap Variabel Bebas Terhadap Variabel Terikat}

Sumbangan efektif digunakan untuk mengetahui besar pengaruh masing-masing variabel bebas terhadap variabel terikat yang dilakukan dengan cara :

a) Sumbangan Efektif $X_{1}$ terhadap $Y$

$$
\begin{aligned}
\mathrm{SE} \% \mathrm{X}_{1} & =\frac{\mathrm{a}_{1} \sum \mathrm{x}_{1} \mathrm{y}}{\mathrm{JK} \mathrm{reg}} \times \mathrm{EGR} \\
& =\frac{253,9768}{405_{a} 7} \times 21,642 \% \\
& =13,55 \%
\end{aligned}
$$

b) Sumbangan Efektif $\mathrm{X}_{2}$ terhadap $\mathrm{Y}$

$$
\begin{aligned}
\text { SE } \% \mathrm{X}_{2} & =\frac{\mathrm{a}_{2} \sum \mathrm{x}_{2} \mathrm{y}}{\mathrm{JKreg}} \times \mathrm{EGR} \\
& =\frac{151,7232}{405_{2} 7} \times 21,64 \% \\
& =8,09 \%
\end{aligned}
$$


Dari hasil perhitungan di atas dapat disimpulkan bahwa sumbangan efektif variabel pembelajaran di dalam jam pelajaran $\left(\mathrm{X}_{1}\right)$ terhadap variabel aktivitas belajar (Y) sebesar 13,55\%, Sumbangan efektif variabel pembelajaran di luar jam pelajar $\left(\mathrm{X}_{2}\right)$ terhadap variabel aktivitas belajar (Y) sebesar 8,09\%.

Adapun maksud dari perhitungan sumbangan efektif untuk mengetahui besar pengaruh masing-masing variabel bebas terhadap variabel terikat. Dari data diatas dapat di simpulkan bahwa Pernyataan diatas menunjukkan bahwa variabel pembelajaran di dalam jam pelajaran yang paling dominan terhadap aktivitas belajar peserta didik. Hal ini terbukti dari proporsi sumbangan pembelajaran di dalam jam pelajaran yang paling besar 13,55\%bila dibandingkan variabel pembelajaran di luar jam pelajaran sebesar $8,09 \%$. Hasil analisis rekapitulasi data tertera dalam tabel dibawah ini :

Tabel 4. Hasil Analisa Data

\begin{tabular}{|c|l|c|c|c|}
\hline No. & \multicolumn{1}{|c|}{ Variabel Bebas } & EGR (\%) & SE (\%) & SR (\%) \\
\hline 1. & $\begin{array}{l}\text { Pembelajaran di dalam jam } \\
\text { pelajaran. } \\
\text { Pembelajaran di luar jam } \\
\text { pelajaran. }\end{array}$ & 13,55 & 62,60 \\
\hline \multicolumn{1}{|c|}{ Jumlah } & $\mathbf{2 1 , 6 4}$ & $\mathbf{2 1 , 6 4}$ & $\mathbf{1 0 0}$ \\
\hline 3. & $\begin{array}{l}\text { Variabel bebas lain yang tidak } \\
\text { diteliti. }\end{array}$ & 78,36 & 78,36 & \\
\hline \multicolumn{2}{|l|}{ Jumlah } & $\mathbf{1 0 0 \%}$ & $\mathbf{1 0 0 \%}$ & $\mathbf{1 0 0 \%}$ \\
\hline
\end{tabular}

\subsection{Pengujian Hipotesis}

\subsubsection{Pengujian Hipotesis Mayor}

Untuk mengetahui sejauh mana hubungan antara pembelajaran di dalam jam pelajaran dan pembelajaran di luar jam pelajaran dengan aktivitas belajar, hipotesis mayor dengan menghitung korelasi antara $\mathrm{x}$ dan y:

$$
\begin{aligned}
& \mathrm{R}_{y(1,2)}=\sqrt{\frac{a_{1} \sum x_{1} y+a_{2} \sum x_{2} y}{\sum y^{2}}} \\
& =\sqrt{\frac{1,4896(170,5)+0,584(259,8)}{1874,5}} \\
& =\sqrt{\frac{253,9768+151,7232}{1874,5}} \\
& =\sqrt{\frac{405,7}{1874,5}} \\
& =\sqrt{0,216431048}
\end{aligned}
$$


$\mathrm{R}_{\mathrm{y}(1,2)}=0,465221504$

$\mathrm{R}_{\mathrm{y}(1,2)^{2}}=\mathbf{0 , 2 1 6}$

Untuk menguji hipotesis mayor, hipotesis kerja (Ha) yang diajukan diubah menjadi hipotesis nihil (Ho) : tidak ada pengaruh pembelajaran menggunakan e-learning berbasis schoology di dalam jam pelajaran dan di luar jam pelajaran terhadap aktivitas belajar peserta didik kelas $\mathrm{X}$ Jurusan Teknik Komputer dan Jaringan SMK Sumber Bunga.

Untuk mengetahui apakah hipotesis mayor yang diajukan diterima atau ditolak maka harga r-hitung dibandingkan dengan r-tabel. Dari hasil perbandingan dengan r-hitung dengan taraf signifikansi 5\% dengan jumlah responden 50 peserta didikdiperoleh r-tabel $=\mathbf{0 , 2 7 9}$ sedangkan hipotesis mayor $\mathrm{R}_{\mathrm{y}}(1,2)$ sebesar $\mathbf{0 , 4 6 5 J a d i} \mathrm{R}_{\mathrm{y}(1,2)}>\mathrm{r}$ - tabel artinya hipotesis kerja $\left(\mathrm{H}_{\mathrm{a}}\right)$ diterima dan hipotesis nihil $\left(\mathrm{H}_{0}\right)$ ditolak, hipotesis kerja yang diterima ialah : ada pengaruh pembelajaran menggunakan $e$ learning berbasis schoology di dalam jam pelajaran dan di luar jam pelajaran terhadap aktivitas belajar peserta didik kelas X Jurusan Teknik Komputer dan Jaringan SMK Sumber Bunga. Nilai tersebut dikonsultasikan dengan tabel interpretasi koefisien korelasi di bawah ini

Tabel 5. Interpretasi Koefisien Korelasi

\begin{tabular}{|c|c|}
\hline Besar Nilai R & Interpretasi \\
\hline Antara $\pm 0,00 \mathrm{~s} / \mathrm{d} \pm 0,20$ & Tidak ada/hampir tak ada \\
Antara $\pm 0,21 \mathrm{~s} / \mathrm{d} \pm 0,40$ & pengaruh \\
Antara $\pm 0,41 \mathrm{~s} / \mathrm{d} \pm 0,60$ & Pengaruh rendah \\
Antara $\pm 0,61 \mathrm{~s} / \mathrm{d} \pm 0,80$ & Pengaruh sedang \\
Antara $\pm 0,81 \mathrm{~s} / \mathrm{d} \pm 1,00$ & Pengaruh tinggi \\
& Pengaruh sempurna \\
\hline
\end{tabular}

Setelah dikonsultasikan dengan tabel interpretasi diatas maka nilai 0,465 terletak antara $\pm 0,41 \mathrm{~s} / \mathrm{d} \pm 0,60$, berarti pengaruh pembelajaran di dalam jam pelajaran terhadap aktivitas belajar adalah pengaruh sedang.

\subsubsection{Pengujian Hipotesis Minor I dan Minor II}

Untuk mengetahui sejauh mana pengaruh pembelajaran di dalam jam pelajaran terhadap aktivitas belajar peserta didikpada mata perangkat keras jaringan kelas X TKJ di SMK Sumber Bunga Tahun 2017/2018, dilakukan analisis data dan kemudian hipotesis minor $\mathrm{X}_{1}$ dan $\mathrm{X}_{2}$ terhadap $\mathrm{Y}$, terlebih dahulu mencari koefisien sederhananya yakni dengan rumus sebagai berikut :

a) Menghitung Koefisien Sederhana 


$$
\begin{aligned}
& r_{y(1)}=\frac{\sum x_{1} y}{\sqrt{\left(\sum x_{1}^{2}\right)\left(\sum y^{2}\right)}} \\
& =\frac{170,5}{\sqrt{(108,5)(1874,5)}} \\
& =\frac{170,5}{\sqrt{203383,25}} \\
& =\frac{170,5}{450,980} \\
& =0,378 \\
& r_{y(2)}=\frac{\sum x_{z} y}{\sqrt{\left(\sum x_{2}{ }^{2}\right)\left(\sum y^{2}\right)}} \\
& =\frac{259,8}{\sqrt{(405,92)(1874,5)}} \\
& =\frac{259,8}{\sqrt{760897,04}} \\
& =\frac{259,8}{872,294} \\
& =0,298 \\
& r_{12}=\frac{\sum x_{1} x_{2}}{\sqrt{\left(\sum \mathrm{x}_{1}^{2}\right)\left(\sum \mathrm{x}_{2}{ }^{2}\right)}} \\
& =\frac{15,2}{\sqrt{(108,5)(405,92)}} \\
& =\frac{15,2}{\sqrt{44042,32}} \\
& =\frac{15,2}{209,863} \\
& =0,072
\end{aligned}
$$

b) Menghitung Koefisisen Korelasi Parsial

Bila diketahui masing-masing koefisien korelasi sederhananya maka dimasukkan dalam koefisien parsialnya masing-masing yaitu :

$$
\begin{aligned}
r_{y 1(2)} & =\frac{r y 1-(r y 2)(r 12)}{\sqrt{\left(1-\mathrm{ry}_{2}^{2}\right)\left(1-\mathrm{r}_{12}^{2}\right)}} \\
& =\frac{0,378-(0,298)(0,072)}{\sqrt{\left(1-0,298^{2}\right)\left(1-0,072^{2}\right)}} \\
& =\frac{0,378-0,021}{\sqrt{(0,9111)(1-0,995)}} \\
& =\frac{0,357}{\sqrt{0,906445}}
\end{aligned}
$$




$$
\begin{aligned}
& =\frac{0,357}{0,952} \\
& =0,375 \\
\mathrm{r}_{\mathrm{y} 2(1)} & =\frac{\mathrm{ry} 2-(\mathrm{ry} 1)(\mathrm{r} 12)}{\sqrt{\left(1-\mathrm{ry}_{1}^{2}\right)\left(1-\mathrm{r}_{2}^{2}\right)}} \\
& =\frac{0,298-(0,378)(0,072)}{\sqrt{\left(1-(0,378)^{2}\right)\left(1-(0,072)^{2}\right)}} \\
& =\frac{0,298-0,027}{\sqrt{(0,857)(0,995)}} \\
& =\frac{0,271}{\sqrt{0,852715}} \\
& =\frac{0,271}{0,923} \\
& =0,294
\end{aligned}
$$

\subsubsection{Pengujian Hipotesis Minor I Pembelajaran di Dalam Jam $\operatorname{Pelajaran}\left(\mathbf{X}_{1}\right)$}

Untuk mengetahui sejauhmana hubungan antara pembelajaran di dalam jam pelajaran $\left(\mathrm{X}_{1}\right)$ dengan aktivitas belajar, hipotesis minor pertama dengan menghitung korelasi antara $\mathrm{X}_{1}$ dan $\mathrm{Y}$ :

$$
\begin{aligned}
\mathrm{r}_{\mathrm{y} 1(1)} & =\frac{\mathrm{ry} 1-(\mathrm{ry} 2)(\mathrm{r} 12)}{\sqrt{\left(1-\mathrm{ry}_{2}^{2}\right)\left(1-\mathrm{r}_{1} 2^{2}\right)}} \\
& =\frac{0,378-(0,298)(0,072)}{\sqrt{\left(1-0,298^{2}\right)\left(1-0,072^{2}\right)}} \\
& =\frac{0,378-0,021}{\sqrt{(0,9111)(1-0,995)}} \\
& =\frac{0,357}{\sqrt{0,906445}} \\
& =\frac{0,357}{0,952} \\
& =0,375
\end{aligned}
$$

Untuk mengetahui minor pertama, hipotesis kerja (Ha) yang diajukan diubah mennjadi hipotesis nihil (Ho) : tidak ada pengaruh pembelajaran menggunakan e-learning berbasis schoology di dalam jam pelajaran dan di luar jam pelajaran terhadap aktivitas belajar peserta didik kelas $\mathrm{X}$ Jurusan Teknik Komputer dan Jaringan SMK Sumber Bunga.

Untuk mengetahui apakah hipotesis minor pertama yang diajukan diterima/ditolak maka harga r-hitung dibandingkan dengan R-tabel. Hasil pengujian hipotesis selengkapnya adalah sebagai berikut : pada 
taraf signifikansi $5 \%$ dengan jumlah responden 50 orang diperoleh $\mathrm{R}$ tabel sebesar 0,279 sedangkan hipotesa minor $\operatorname{Ryl}_{(2)}=\mathbf{0 , 3 7 5}$. Jadi Ryl $1_{(2)}$ hitung lebih besar dari r-tabel artinya hipotesis kerja (Ha) diterima dan hipotesis nihil (Ho) ditolak, hipotesis kerja yang diterima ialah ada pengaruh pembelajaran menggunakan e-learning berbasis schoology di dalam jam pelajaran dan di luar jam pelajaran terhadap aktivitas belajar peserta didik kelas X Jurusan Teknik Komputer dan Jaringan SMK Sumber Bunga.

Setelah dikonsultasikan dengan tabel interpretasi diatas, maka 0,375 terletak antara $\pm 0,21 \mathrm{~s} / \mathrm{d} \pm 0,40$ berarti pengaruh pembelajaran di dalam jam pelajaran terhadap aktivitas belajar adalah pengaruh rendah.

\subsubsection{Pengujian Hipotesis Minor II Pembelajaran di Luar Jam Pelajaran} $\left(\mathbf{X}_{2}\right)$

Untuk mengetahui sejauh mana hubungan antara pembelajaran di luar jam pelajaran $\left(\mathrm{X}_{2}\right)$ dengan aktivitas belajar, hipotesis minor kedua dengan menghitung korelasi antara $\mathrm{X} 2$ dan $\mathrm{Y}$ :

$$
\begin{aligned}
r_{\mathrm{y} 2(1)} & =\frac{\mathrm{ry} 2-(\mathrm{ry} 1)(\mathrm{r} 12)}{\sqrt{\left(1-\mathrm{ry}_{1}^{2}\right)\left(1-\mathrm{r}_{2}^{2}\right)}} \\
& =\frac{0,298-(0,378)(0,072)}{\sqrt{\left(1-(0,378)^{2}\right)\left(1-(0,072)^{2}\right)}} \\
& =\frac{0,298-0,027}{\sqrt{(0,857)(0,995)}} \\
& =\frac{0,271}{\sqrt{0,852715}} \\
& =\frac{0,271}{0,923} \\
& =0,294
\end{aligned}
$$

Untuk menguji hipotesis minor kedua kerja (Ha) yang diajukan diubah dahulu menjadi hipotesa nihil (Ho) menjadi : tidak ada pengaruh pembelajaran menggunakan e-learning berbasis schoology di dalam jam pelajaran dan di luar jam pelajaran terhadap aktivitas belajar peserta didik kelas X Jurusan Teknik Komputer dan Jaringan SMK Sumber Bunga.

Untuk mengetahui apakah hipotesis minor kedua yang diajukan diterima/ditolak maka harga R-hitung dibandingkan dengan R-tabel sebagai : pada taraf signifikan 5\% dengan sampel 50 diperoleh $\mathrm{R}$-tabel $=$ 0,279 . Hipotesis minor kedua Ry2(1) $=\mathbf{0 , 2 9 4}$.

Untuk mengetahui apakah hipotesis minor kedua yang diajukan diterima atau ditolak maka harga $\mathrm{R}$-hitung dibandingkan dengan $\mathrm{R}$-tabel. Dari hasil perbandingan dengan R-hitung dengan taraf signifikansi 5\% dengan jumlah responden 50 orang diperoleh $\mathrm{R}$-tabel $=0,279$ sedangkan hipotesa minor kedua Ry2(1) sebesar 0,94 Jadi R- hitung lebih besar dari R-tabel artinya hipotesis kerja (Ha) diterima dan hipotesis nihil (Ho) 
ditolak, hipotesis kerja yang diterima ialah : ada pengaruh pembelajaran menggunakan e-learning berbasis schoology di dalam jam pelajaran dan di luar jam pelajaran terhadap aktivitas belajar peserta didik kelas $\mathrm{X}$ Jurusan Teknik Komputer dan Jaringan SMK Sumber Bunga.

Setelah dikonsultasikan dengan tabel interpretasi diatas maka nilai 0,294 terletak diantara $\pm 0,21 \mathrm{~s} / \mathrm{d} \pm 0,40$ berarti pengaruh pembelajaran di luar jam pelajaran terhadap aktivitas belajar adalah pengaruh rendah.

Untuk lebih jelasnya dari hasil seluruh perhitungan mencari besar pengaruh dapat dilihat pada tabel berikut :

Tabel 6. Pengujian Hipotesa Mayor dan Minor

\begin{tabular}{|c|c|c|c|c|}
\hline Hipotesis & R.Empirik & R.Tabel & Keputusan & Sumbangan \\
\hline Ha Mayor & 0,465 & 0,279 & Signifikan & $21,64 \%$ \\
Ha Minor 1 & 0,375 & 0,279 & Signifikan & $13,55 \%$ \\
Ha Minor 2 & 0,294 & 0,279 & Signifikan & $8,09 \%$ \\
\hline
\end{tabular}

\subsection{Pembahasan/Interpretasi}

Dari hasil penelitian yang diperoleh dengan menggunakan rumus analisis variansi garis regresi menghasilkan Ry $(1,2)$ empirik sebesar 0,465 , apabila dikonsultasikan dengan r-tabel dengan $\mathrm{N}$ sebanyak 50 responden dan taraf signifikansi 5\% diperoleh 0,279 perhitungan tersebut dimaksudkan untuk membuktikan hipotesa kerja mayor dengan menggunakan uji signifikansi.

Dari hasil perhitungan analisis variansi garis regresi diperoleh Freg sebesar 6,4745. Dan apabila dikonsultasikan dengan $\mathrm{F}$ tabel untuk $\mathrm{db}=2 \mathrm{dan} \mathrm{db}$ $=47$ dengan taraf signifikansi 5\% diperoleh 3,1951. Dengan demikian dari hasil perhitungan tersebut menunjukkan Freg lebih besar dari F-tabel yang berarti signifikansi secara mayor pembelajaran di dalam jam pelajaran dan pembelajaran di luar jam pelajaran terhadap aktivitas belajar peserta didik.

Untuk hasil analisis minor pertama untuk uji signifikansi antara pembelajaran di dalam jam pelajaran terhadap aktivitas belajar peserta didik yang diperoleh T-hitung 2,802 dan taraf signifikansi 5\%. Tabel distribusi $t$ dicari pada $a=5 \%: 2=2,5 \%$ (uji 2 sisi) dengan derajat kebebasan (df) n-k-1 atau 50-2-1 = 47 ( $\mathrm{n}$ adalah jumlah kasuks dan $\mathrm{k}$ adalah jumlah variabel independen). Dengan pengujian 2 sisi (signifikansi $=0,025$ ) untuk t-tabel sebesar 2,012. Jadi T-hitung 2,802 lebih besar 2,012 berarti Ho ditolak dan Ha 
diterima pembelajaran di dalam jam pelajaran terhadap aktivitas belajar peserta didik.

Untuk hasil analisis minor kedua untuk uji signifikansi antara pembelajaran di luar jam pelajaran terhadap aktivitas belajar peserta didik yang diperoleh hasil T-hitung 2,131 dan taraf signifikansi 5\%. Tabel distribusi t dicapai pada $a=5 \%: 2=2,5 \%$ (uji 2 sisi) dengan derajat kebebasan (df) n-k-1 atau 50-2-1 = 47 ( $\mathrm{n}$ adalah jumlah kasus dan $\mathrm{k}$ adalah jumlah variabel independen). Dengan pengujian 2 sisi (signifikansi $=0,025$ ) untuk t-tabel sebesar 2,012. Jadi T-hitung 2,131 lebih besar 2,012 berarti Ho ditolak dan Ha diterima pembelajaran di luar jam pelajaran terhadap aktivitas belajar peserta didik.

Berdasarkan analisa data di atas, maka hipotesa kerja mayor yang berbunyi ada pengaruh pembelajaran menggunakan e-learning berbasis schoology di dalam jam pelajaran dan di luar jam pelajaran terhadap aktivitas belajar peserta didik kelas X Jurusan Teknik Komputer dan Jaringan SMK Sumber Bunga.

Selanjutnya dalam efektifitas garisregresi diperoleh sebesar $21,64 \%$. Ini berarti sumbangan efektif dari keseluruhan prediktor aktivitas belajar peserta didik memberikan sumbangan sebesar $21,64 \%$ sedangkan prediktor yang lain tidak diteliti memberikan sumbangan sebesar 78,36\%.

Sumbangan efektif (SE) prediktor $\left(\mathrm{X}_{1}\right)$ pembelajaran di dalam jam pelajaran terhadap kriterium (Y) aktivitas belajar peserta didik 13,55\%. Sumbangan efektif $(\mathrm{SE})$ prediktor $\left(\mathrm{X}_{2}\right)$ pembelajaran di luar jam pelajaran terhadap kreterium (Y) aktivitas belajar peserta didik 8,09\%, ini menunjukkan bahwa pembelajaran menggunakan e-learning berbasis schoology di dalam jam pelajaran lebih berpengaruh terhadap aktivitas belajar peserta didik dibandingkan pembelajaran di luar jam pelajaran.

\section{KESIMPULAN}

Berdasarkan penelitian dan analisis statistik yang dilakukan diperoleh kesimpulan sebagai berikut :

a. Ada pengaruh e-learning berbasis schoology terhadap aktivitas belajar peserta didik kelas X Jurusan Teknik Komputer SMK Sumber Bunga Tahun Pelajaran 2017/2018, hal ini dibuktikan dengan meningkatnya aktivitas belajar peserta didik berdasarkan pengamatan dan hasil angket yang diisi oleh peserta didik.

b. Pengaruh e-learning berbasis schoology didalam jam pelajaran sebesar 13,55\% terhadap aktivitas belajar peserta didik kelas X Jurusan Teknik Komputer SMK Sumber Bunga.

c. Pengaruh e-learning berbasis schoology diluar jam pelajaran sebesar 8,09\% terhadap aktivitas belajar peserta didik kelas X Jurusan Teknik Komputer SMK Sumber Bunga.

d. Pemanfaatan e-learning berbasis schoology didalam jam pelajaran lebih berpengaruh dibandingkan diluar jam pelajaran terhadap aktivitas belajar peserta didik. 


\section{DAFTAR PUSTAKA}

Aminoto dan Pathoni. 2014. Aplikasi Schoology sebagai Pembelajaran, hal : 21. Bandung. Brown. 2010. Manfaat E-learning, hal :168-170. Jakarta : Bumi Aksara.

Daryanto. 2008. Metode Penelitian, hal : 33. Bandung.

Faisal, Sanapiah. 2005. Metode Penelitian, hal :122. Malang.

Faisal, Sanapiah. 2009. Statistik, hal : 52. Yogyakarta.

Hadari Nawawi dan Daryanto. 2008. Pengumpulan Data, hal : 111. Surabaya.

Hadi, Sutrisno. 2006. Metodologi Research, hal : 68 - 89. Bandung : Alfabeta.

Hadi, Sutrisno. 2008. Metode Research, hal :188. Bandung : Alfabeta.

Hadi, Sutrisno. 2011. Metode Research, hal : 65-67. Bandung : Alfabeta.

Jessica. 2009. Metode Pembelajaran, hal: 15-21. Depok : PT. Raja Grafindo Persada.

Kudos, Website. 2002. Pembelajaran E-learning, hal : 23. Bandung : Alfabeta.

Lewis. 2002. E-learning (Pembelajaran Elektronik) Sebagai Salah Satu Alternatif Kegiatan Pembelajaran, hal : 67. Yogyakarta.

Lukmana. 2006. Belajar Pembelajaran, hal : 16. Jakarta : PT.Gramedia Pustaka Umum.

Mulyono. 2001. Aktivitas Belajar, hal : 26. Jakarta : PT. Raja Grafindo Persada.

Ramadhani. 2012. Metode Pembelajaran E-learning Berbasis Schoology, hal : 14. Bandung: CV Wacana Prima.

Rochman Natawijaya dan Rosalia. 2005. Efektifitas Peserta Didik Dalam Pembelajaran, hal: 31- 45. Bandung : Jurnal Ilmiah Pendidikan.

Rosalia. 2005. Peran Peserta Didik, hal : 101. Yogyakarta.

Santyasa. 2013. E-Learning Dalam Pendidikan Jarak Jauh, hal : 101. Yogyakarta.

Sembel. 2004. Belajar dan Pembelajaran E-Learning, hal : 15. Jakarta.

Soekartawi. 2012. Pembelajaran E-Learning, hal : 20. Bandung : Alfabeta.

Sugiyono. 2014. Dasar-Dasar Statistik, hal :183-184. Bandung : Alfabeta.

Sukardi. 2013. Dasar-Dasar Statistik, hal : 15 dan 165. Jakarta : Alfabeta.

Tafiardi, dkk. 2005. Pengembangan E-learning Teori dan Desain. Bandung : PT. Remaja Rosdakarya.

Usman, Husaini. 2007. Pembelajaran Statistik, hal : 61-73. Bandung : Alfabeta.

[25] Usman, Husaini. 2009. Metode Penelitian, hal : 54. Bandung : Alfabeta.

Zulfikri. 2008. Aktivitas Peserta Didik, hal : 56. Jakarta : PT. Raja Grafindo Persada. 